\title{
DIE NEDERDUITSE GEREFORMEERDE KERK EN DIE SUID-AFRIKAANSE RAAD VAN KERKE
}

\author{
C F A BORCHARDT
}

\begin{abstract}
The Dutch Reformed Church and the South African Council of Churches

The General Missionary Conference which was founded in 1904 became the Christian Council of South Africa in 1936. In 1940 a founder member, viz. the Transvaal Synod of the Dutch Reformed Church withdrew from the council. In 1968 a change of name to the South African Council of Churches reflected a deeper involvement in social and political matters and it gradually also became more representative of the black Christian point of view. Despite various invitations, the Dutch Reformed Church has not rejoined the Council and relations have been very strained, but at its last synod in 1986 the Dutch Reformed Church decided that informal discussions could be held.
\end{abstract}

\section{Die stigting van die Christenraad van Suid-Afrika}

Samewerking tussen kerke in Suid-Afrika het, soos elders in die wêreld, veral op die gebied van die sending plaasgevind. Ons kan ook wys op die stigting in 1857 van 'n tak van die Evangeliese Alliansie in Kaapstad. Prof. $\mathrm{N} J$ Hofmeyr het twee jaar later by die opening van die Teologiese Seminarium in Stellenbosch gekla dat daar geen pogings aangewend is om al die Christene in die land byeen te bring nie. In 1860 is ' $n$ groot interkerklike konferensie op inisiatief van die Ned. Geref. Kerk in Worcester gehou. 'n Geestelike oplewing het hieruit voortgespruit en aanleiding gegee tot verdere sending-en algemene konferensies oor die hele land. ${ }^{11}$

Die American Board het die leiding geneem in 1881 met die stigting van 'n Natal Missionary Conference en 'n paar dekades later het hul inisiatief gelei tot die stigting van die Algemene Sendingkonferensie op 13 Julie 1904. Die lede van hierdie konferensie het as indiwidue deelgeneem en het nie hul sendinggenootskappe of kerke verteenwoordig nie. Predikante van sowel die Ned. Geref. Kerk in die Kaap as die Ned. Herv. of Geref. Kerk in Transvaal het hieraan deelgeneem. ${ }^{21}$

Vanaf 1904 tot 1932 was agt byeenkomste van hierdie Algemene Sendingkonferensie gehou waartydens die klem geval het op evangelisasie, onderlinge samewerking en die belange van die swart mense. 
Teen die einde van twintigerjare was $\mathrm{J} H$ Oldham en later $\mathrm{dr}$. John $\mathrm{R}$ Mott van die Internasionale Sendingraad uitgenooi om Suid-Afrika te besoek. ${ }^{3 \prime}$ Dr. Mott kon eers in 1934 hierheen kom en tydens sy laaste byeenkoms op 15-16 Mei 1934 in Bloemfontein het die aanwesiges besluit om die Christenraad van Suid-Afrika te stig. ' $n$ Voortsettingskomitee van 29 lede is benoem waaronder die name voorkom van di. A $F$ Louw (konvenor), J M N Breedt, W Nicol, J Reyneke, J G Strydom, G L van Heerde en $A J$ van Wyk van die Ned. Geref. Kerke. Op die uitvoerende komitee van hierdie voortsettingskomitee het ds. A F Louw as voorsitter gedien en ook ds. W Nicol. ${ }^{41}$

Na heelwat voorbereidingswerk het die Voortsettingskomitee op 24 Junie 1936 in Bloemfontein besluit om die Christenraad van Suid-Afrika te stig en op Donderdag 25 Junie is die eerste vergadering gehou. $W$ Nicol is tot die eerste president verkies, $J M$ du Toit as voltydse algemene sekretaris en op die uitvoerende komitee het $J$ Reyneke gedien. ${ }^{5 \prime}$ Die president, W Nicol het, soos iemand dit uitgedruk het, "'n entoesiastiese maar realistiese ${ }^{\prime 6}$ ) rede gehou. Hy het daarop gewys dat die byeenkoms nie buitengewoon was nie maar dat hulle voortgedra word op die gety van samewerking wat aan hierdie eeu eie is. Hy het voortgegaan deur daarop te wys dat die Raad noodsaaklik was ter wille van 'n opname van die stand van die Christelike sending in Suid-Afrika en om oorvleueling tussen sendinge wat veronderstel is om vriendskaplik teenoor mekaar ingestel te wees, uit te skakel. Die kerke sou ook veel meer invloed kon uitoefen as hulle hul onderlinge verskille kon uitstryk voordat hulle die regering nader oor sake wat die swart mense en sending raak. Ten opsigte van swart onderwys en mediese sending was nouer samewerking tussen die kerke dringend noodsaaklik. Hierdie Raad sou 'n wonderlike geleentheid bied om ' $n$ verenigde getuienis te lewer ten behoewe van die Christendom in Suid-Afrika.

Nicol het egter ook sekere probleme voorsien. Daar was verskillende menings ten opsigte van die vraag oor samewerking met ander rasse. Oor die politiek het hy verklaar dat hy as predikant dit nie wou aanraak nie maar het tog openlik verklaar dat hy 'n nasionalis was en in die bestaan van die Afrikanernasie met ' $n$ eie taal en kultuur geglo het. Die Engelse was ook in hul hart nasionaliste "and I claim that we cannot proceed on any basis of sloppy internationalism but rather on the basis of a happy, confident, nationalism aware of itself yet granting an equal right of existence to its fellow".

Ander struikelblokke op die weg van samewerking was verskille ten opsigte van die lobola-stelsel, die gebruik van "kafferbier" ;sook ander gebruike onder die swart mense. 'n Ander struikelblok volgens Nicol was dat die Christelike kerke "still reveal a pathetic lack of the spirit of 
comity". Samevattend kon mens praat van die gebrek aan die ware Gees van Christus in die kerk of soos dr. Mott sou gesê het "the low temperature of the Churches".

Die Christenraad sou hom nie vir organiese kerkvereniging beywer nie maar sou raadplegend en adviserend wees. Oor die taalmedium het hy veronderstel dat elke lid sy eie taal sou kon gebruik soos in die parlement. Hy het afgesluit met die woorde "the spiritual church dare not be isolated. Isolation is death".?)

Die sekretaris van die Christenraad het kantoor no. 5 op die eerste vloer van die Voortrekker Gedenksaal van die Ned. Herv. of Geref. Kerk van Transvaal betrek. ${ }^{8}$ ' Die tweede vergadering van die Christenraad wat op 21 Januarie 1937 begin het, is geopen met Skriflesing en gebed in Afrikaans deur ds. A J van Wyk, moderator van die Kaapse Ned. Geref. Kerk. Die president, ds. (later dr.) W Nicol het onder andere weer eens by die taalprobleem stilgestaan. "The Afrikander felt that his language is the indigenous form of European speech in South Africa." Hy het gewys op die gebruik van Afrikaans in skole, die parlement ens. en vervolg: "Afrikanders believed that in the course of another generation it would be the universal language of the Union." Hulle het nie daarop aangedring om in Afrikaans aangespreek te word nie behalwe wanneer hulle te doen gehad het met betaalde werknemers van die staat of ook hierdie Christenraad. Alle ander mense was vry om hul eie taal te gebruik. "It is not bi-lingualism that is demanded as a return for their hearty cooperation; it is bi-auralism." Die Afrikaanssprekendes het gevoel dat "when they come here they are not understood; the Council listens to them with tolerant and admirable deafness." Hy het voorgestel dat elkeen in sy eie taal moes praat sonder 'n tolk en dat elke lid 'n ernstige poging moes aanwend om te verstaan wat deur die ander lede gesê is: "Verily, bi-lingualism is the cross of South Africa. That we cannot alter, but we can at least bear our cross handsomely". Nicol het 'n ernstige oproep op die Afrikaanse kerke en gemeenskap gedoen om nie vanweë die taalprobleem afsydig te staan teenoor die Christenraad nie. Die gebrek aan tweetaligheid is ' $n$ verbygaande fase in die geskiedenis van Suid-Afrika. "The great task before us demands that nothing of a temporary nature, not even tongues which will pass away, should prevent our co-operation."

'n Ander struikelblok was die verskillende opvattinge oor byna alle sake wat die swart mense geraak het. Vir sommige moes die Christenraad nie te vinnig beweeg nie, terwyl ander weer ongeduldig geraak het omdat die pas te stadig was. Al bogenoemde mog ontmoedigend en hopeloos geklink het "to people who do not appreciate the genius of South Africa and do not know that all our best things have 
been born out of conflict and strife." Mense moes saamkom in die Christenraad om saam die probleme te bestudeer. Indiwiduele groepe was vry om onafhanklik op te tree as die besluite van die Christenraad nie hulle mening ten volle weerspieël het nie. "Some council of the kind was necessary in South Africa, if the Christian Churches were to give our nation a true picture of Christ." 9 !

Die Ned. Herv. of Geref. Kerk is verteenwoordig deur W Nicol en J Reyneke terwyl G B A Gerdener, A F Louw, G L van Heerde en A J van Wyk van die Kaapse Kerk gekoöpteer is as geassosieerde lede. Tydens die openbare vergadering het $Z \mathbf{R}$ Mahabane vertel wat die swart mense van die Christenraad verwag het. "We do not seek social equality with the European, nor do we ask for racial admixture, but we do consider that in religion and politics there should be equal opportunities for all sections of the population and that there should be no discrimination based on artificial structures." Op die Vrydagoggend het 'n leraar van die Hermannsburg Evangelies Lutherse Kerk die verrigtinge begin met Skriflesing in Afrikaans en ' $n$ gebed in Duits. ${ }^{10}$ )

Ek het uitvoerig ingegaan op die taalkwessie want dit sou uiteindelik een van die belangrikste redes vir die onttrekking van die Afrikaanse kerke wees. Die doel van die Christenraad was om 'n assosiasie van kerke en sendinggenootskappe vir die uitbreiding van die koninkryk van God te wees. Daar was sewe komitees wat onderskeidelik verantwoordelik was vir evangelisasie (die sameroeper was ds. J Reyneke, sendingsekretaris van die Ned. Herv. of Geref. Kerk Transvaal), onderwys, literatuur, mediese werk, welsyn van die swart mense, vrouewerk en jeugbewegings.

\section{Die houding van die Ned. Geref. Kerke}

Die Raad van Kerke het op sy vergadering in Mei 1935 'n aantal wysiginge aan die konsep-grondwet van die voorgestelde Nasionale Christenraad aangebring. ' $n$ Voorstel van $W$ Nicol en J M Louw, waarin die oortuiging uitgespreek is dat die stigting van ' $n$ Algemene Sendingraad vir die Unie van Suid-Afrika tot nut van die koninkryk van God sou wees, is aanvaar. Verder moes die Gefedereerde Kerke betyds toesien dat indien so ' $n$ sendingraad gestig sou word, die konstitusie van daardie raad bevredigend sou wees vir die sendingbeleid van die Ned. Geref. Kerke en dat hulle in daardie geval by die sendingraad behoort aan te sluit. ${ }^{11)}$ Let daarop dat hulle die voorgestelde raad ' $n$ "sendingraad" genoem het.

Tydens die sitting van die Kaapse sinode in Oktober 1936, was, na druk bespreking en ' $n$ hele aantal voorstelle, besluit dat hulle op dié tydstip geen vrymoedigheid gehad het om by die Christenraad aan te 
sluit nie, dog geneë was tot samewerking. Dit is aan die moderatuur opgedra om na gelang van omstandighede handelend op te tree. ${ }^{121}$

Op die vergadering van die Raad van Kerke in Maart 1937 was aansluiting by die Christenraad weer eens ter sprake. Die sg. Naturellesakekommissie het in hulle verslag daarop gewys dat hulle voorgestelde wysiginge aan die konsep konstitusie van die Christenraad wel nie woord vir woord aangebring is nie maar dat daar tog aan al hul wense voldoen is. Wat die kwessie van botsing met ons beleid betref, het hulle aangetoon dat die Christenraad kragtens sy konstitusie aan bepaalde beperkings onderhewig was, naamlik dat dit buite sy bevoegdheid was om vraagstukke in verband met geloof en toesig waarop kerklike verskilpunte berus, te behandel. Die Christenraad was ook nie bevoeg om kerke of liggame sonder hul toestemming tot enige beleid of optrede of enige geldelike verpligting te verbind nie. Die verteenwoordigers van die Ned. Geref. Kerke is ook met drie vermeerder sodat hulle tien sou hê. Die Kommissie vir Naturellesake wou dus dat die Raad van Kerke by al vier die Gefedereerde Kerke en die drie Sendingkerke aanbeveel dat hulle by die Christenraad aansluit. Na heelwat bespreking wat oor twee dae gestrek het, het die Raad van Kerke besluit om by die sinodes van die Gefederéerde Kerke aan te beveel om vereers op grondslag van die sendingbeleid, soos neergelê in 1935, met die Christenraad saam te werk. ${ }^{13)}$ Die Raad van Kerke het pas in 1935 'n eenvormige sendingbeleid goedgekeur, vandaar die aandrang op handhawing daarvan.

Die sinode van die Ned. Herv. of Geref. Kerk in Transvaal het op 7 April 1937 met sy sitting begin. Die Sinodale Kommissie het gerapporteer dat hy op grond van die besluit van die Raad van Kerke van 1935 besluit het om voorlopig by die Christenraad aan te sluit en het die moderator (W Nicol) en die sendingsekretaris (J Reyneke) benoem as offisiële verteenwoordigers. Die Sendingkerk van Transvaal het ook besluit om by die Christenraad aan te sluit met die voorbehoud dat indien die moederkerk sou onttrek, hulle dit ook sou doen. Die sinode het die aansluiting by die Christenraad bekragtig. ${ }^{14)}$

Die Vrystaatse sinode, wat ook in April 1937 byeengekom het, het besluit dat hy nie sy weg oopsien om by die Christenraad aan te sluit nie omdat: a) dit nie uit die konstitusie van die liggaam geblyk het dat sy werksaamhede hom nie sou bepaal by die belange van die Sendingkerke nie; b) die basis van verteenwoordiging hom nie bevredig het nie (Anglikane 6, Metodiste 6 en N.G. Kerke en Sendingkerke 10); c) op grond van Artikel 11 van die konstitusie dit nie duidelik was wat sy uiteindelike finansiële verpligting sou wees nie; d) daar nie 'n duidelik omlynde sendingbeleid in die konstitusie neergelê is wat kon vergelyk met die verklaarde sendingbeleid van die Gefedereerde Kerke nie. ${ }^{15)}$ Die 
Vrystaatse Kerk het ten minste 'n duidelike standpunt ingeneem. Wat sy eerste beswaar betref wil ek opmerk dat uit die omskrywing van die doel en werksaamhede van die Christenraad blyk dat dit vir die Raad gegaan het om die doeltreffende voortplanting van die evangelie in die wydste betekenis van die woord. In die konstitusie is gepraat van die bevordering van broederskap tussen die kerke sodat ' $n$ atmosfeer van onderlinge respek en vertroue geskep sou word sodat die land gelei sou word tot gesamentlike voorbidding, onderlinge gedagtewisseling en gesamentlike beraming van planne en eendragtige optrede. Formeel het die Vrystaatse sinode dus wel gelyk gehad. Wat die derde beswaar betref was dit nie duidelik uitgespel in Artikel 10 van die konstitusie wat die verpligtinge sou wees nie. Elke kerk sou sy eie verteenwoordigers se onkoste moes dra maar daar sou ook voorsiening gemaak moes word vir reis- en kantoorkoste van die Uitvoerende Komitee en die sekretariaat. Die vierde beswaar oor die sendingbeleid was 'n groot probleem. Ons moet onthou dat dit die Vrystaatse inisiatief in 1931 was wat uiteindelik gelei het tot die aanvaarding van 'n eenvormige sendingbeleid deur die Raad van Kerke in 1935. Daarteenoor was dit duidelik dat die Christenraad in 'n ander rigting beweeg het as die Ned. Geref. Kerke.

In briewe wat in Die Kerkbode verskyn het in die eerste halfjaar van 1937, is daar steun uitgespreek vir die Christenraad soos byvoorbeeld $G$ B A Gerdener en M W Retief, maar daar was ook briewe van kritiek. ${ }^{16}$ )

Op die vergadering van die Raad van Kerke in Maart 1939 het die Kommissie vir Naturellesake gerapporteer dat die kerk in Transvaal en hul Sendingkerk wel by die Christenraad aangesluit het en dat hulte (die R.v.K.) daarom ' $n$ waaksaamheidskommissie aangestel het om in voeling met die Christenraad te bly. Hierdie kommissie het egter nog nie aktief opgetree nie. ${ }^{17 \text { ) }}$

'n Ander belangrike ontwikkeling was die totstandkoming van die Tussenkerklike Sendingraad. Na aanleiding van die Uniale Sendingkonferensie wat in 1938 in Bloemfontein gehou is, is daar voorgestel dat die sinodes van die Gefedereerde Kerke 'n tussenkerklike sendingraad daarstel. Die vergadering van die Raad van Kerke het die saak bespreek en besluit dat op voetspoor van die Algemene Armsorg 'n dergelike sendingraad in die lewe geroep moes word om die Gefedereerde Kerke op sendinggebied te verteenwoordig. Hierdie voorgestelde raad sou die werksaamhede van die Kommissie vir Naturellesake oorneem. ${ }^{18)} \mathrm{Al}$ die sinodes het hiertoe ingestem en die Federale Sendingraad het in 1942 tot stand gekom.

\section{Die Ned. Geref. Kerke onttrek}

Die derde volle vergadering van die Christenraad van Suid-Afrika is op 18 
tot 20 April 1939 gehou. In sy presidentsrede het ds. Nicol, naas faktore wat meegewerk het tot samewerking, ook gewys op faktore wat in die pad gestaan het van samewerking, soos die polities-sosiale toepassing van die evangelie. Hy het ook melding gemaak van die feit dat medeChristene ' $n$ parallelle organisasie oorweeg het waar die ander taal die heersende medium sou wees en waarin die ander standpunt van die sosiale toepassing van die evangelie in die Suid-Afrikaanse toestande genoegsaam verteenwoordig sou word. Hy het voorts gesê dat ons begin het met twee rasse, gaandeweg twee tale erken het asook twee hoofstede en waarom sou ons nie twee nasionale rade hê nie? Die doel met die Christenraad is ook verkeerd verstaan. Dit was nie die spreekbuis van die kerk in Suid-Afrika nie maar is gestig om studie te vergemaklik. Elke kerk moes homself afvra of die boodskap wat hy preek die wil van God is en of hy dit moes heroorweeg in die lig van wat die susterkerke doen. Die Christenraad was soms ook "called upon to manifest such unity as does already exist among the churches. It will do that by its very existence." Ons geleenthede moet ons, aldus Nicol, bymekaarbring, onder andere die geleentheid tot evangelisasie en onderwys aangesien ons dieselfde lewe in Jesus Christus deel. ${ }^{19}$ )

Op die sinodesitting van die Ned. Herv. of Geref. Kerk in April 1940 het di. Nicol en Reyneke 'n baie positiewe verslag oor die Christenraad aan die sinode voorgelê. Hulle was diep onder die indruk van die belangrikheid van die Raad en die nuttigheid van sy werk. Die Christenraad was die enigste liggaam in Suid-Afrika wat 'n geleentheid gebied het vir die gesamentlike optrede van al die Protestantse kerke in sake van gemeenskaplike belang. Hulle het ook daarop gewys dat die Raad hom aanvanklik bepaal het by sendingaangeleenthede "maar dit het spoedig geblyk dat die Raad 'n magtige faktor kan word in die land, vir die bevordering van die Christendom in die algemeen". Daar was bv. gesamentlik opgetree teen die dobbeleuwel en by die owerheid het hulle hul invloed laat geld teen die vertoon van ongewenste rolprente aan swart mense. Daar is ook gesamentlik getuienis afgelê voor regeringskommissies oor gesondheidsdienste aan swart mense en onderwysaangeleenthede. Daar is ook gewys op die belangrike publikasie, nl. die Christen-handboek van Suid-Afrika. Die Christenraad het ook probeer bemiddel ten opsigte van die internering van Duitse sendelinge en hulle het die Finse sendelinge in Ovamboland wat met groot moeilikhede te kampe gehad het, gehelp. Die verslag is deur die sinode aanvaar. ${ }^{20}$ )

$\mathrm{Na}$ hierdie gloeiende aanbeveling ten gunste van die Christenraad is dit ietwat vreemd dat ds. Nicol, op dié stadium een van die visepresidente van die Christenraad, op 8 Mei 1940 aan ds. F Stakes, die president geskrywe het en nadat hy hom meegedeel het dat daar 'n 
Federale Sendingraad vir die Ned. Geref. Kerke gestig gaan word, vervolg het dat hoewel hy die Christenraad ondersteun het, hy nou teleurgesteld is om die volgende redes: a) die taalkwessie; b) die verskillende opvattinge oor die verhouding tussen blankes en swartes; c) dat hy min hoop het dat die ander Ned. Geref. Kerke sou aansluit. Hy meen daarom dat die Christenraad tevrede sal moet wees om die Engelssprekende kerke te verteenwoordig terwyl die Afrikaanse kerke in die voorgestelde nuwe raad sal saamwerk. Nicol het die Ned. Herv. of Geref. Kerk se Sendingkommissie versoek om hom nie weer op die Christenraad aan te stel nie. Hy het sy brief afgesluit met die woorde: "I need hardly say dear Mr. Stakes, how it grieves me to take this step. A great body, uniting the voice of Protestant Christendom in South Africa, has been my dream for years. You and I are, however, not to see it, and we can but hope that the next generation will. Possibly the Federated Missionary Council and the Christian Council might in due time set up machinery for a measure of co-operation."21)

Die Christenraad het op 28 Junie 1940 'n buitengewone vergadering gehou en besluit om afvaardigings na die Kaapse en Transvaalse kerke te stuur. Die Kaapse afvaardiging wat die Christenraad se verteenwoordigers ontmoet het, het by monde van ds. A F Louw laat weet dat die Kaapse Kerk nader aan affiliasie was as ooit tevore maar dat die houding van die kerk in Transvaal die belangrikste struikelblok was in die weg tot aansluiting. Die Transvaalse afvaardiging, onder leiding van ds. Nicol, het op sy beurt aan die verteenwoordigers van die Christenraad gesê dat die onus op die Kaap rus omdat hulle nog nooit hulle gewig agter die Christenraad gegooi het nie en indien die Kaapse kerk sy houding sou heroorweeg, die Transvaalse kerk ook sy houding in heroorweging sou neem. Op die sinodesitting van die Kaapse kerk in Oktober 1940 is, ten spyte van roerende pleidooie deur o.a. A F Louw ten gunste van aansluiting by die Christenraad, besluit om te volstaan met die vorige besluit van 1936. Die vrees vir oorheersing deur die ander kerke, omdat die Ned. Geref. Kerk slegs 10 verteenwoordigers uit die 45 lede op die Christenraad sou hê, was blykbaar 'n belangrike argument in die debat want "ons beleid" sou bedreig word. ${ }^{22)}$ Hierdie besluit van die Kaapse sinode het daartoe aanleiding gegee dat die Church of the Province hom onttrek het aan die Christenraad in 1940 en die voortbestaan van die Raad in gevaar gestel het. In Junie 1941 het die biskoppe egter hul besluit heroorweeg en weer by die Christenraad aangesluit. ${ }^{23)}$

In die verslag van die Sinodale Kommissie aan die sinodesitting van die Ned. Herv. of Geref. Kerk in Julie 1944 is gerapporteer dat die Sinodale Sendingkommissie se verteenwoordiger op die Christenraad bedank het (moontlik was dit te wyte aan die feit dat ds. J Reyneke, die 
sendingsekretaris, op 21 Maart 1941 na die gemeente Pretoria (Bosmanstraat) beroep is). Die Sinodale Kommissie het verder gemeld dat die besluit van die sinode, om lid te wees van die Christenraad, sedert 1941 nie uitgevoer is nie. Die sinode moes nou bepaal of hy sy besluit van 1937 tot lidmaatskap van die Christenraad wou handhaaf. Die Sinodale Kommissie het aanbeveel dat sy lidmaatskap beëindig word.

Die Sinode het die optrede van die Sendingkommissie en die Sinodale Kommissie om uit te tree uit die Christenraad goedgekeur en 'n beskrywingspunt van die leraar van Pretoria (waarskynlik ds. Reyneke) dat onder sekere voorwaardes wel by die Christenraad aangesluit word, verwerp. Die sinode het besluit om sy lidmaatskap van die Christenraad te beëindig omdat die ander Gefedereerde Kerke nie aangesluit het nie en aangesien die Federale Sendingraad in die lewe geroep is, die moontlikheid van bespreking van sendingprobleme tussen die Federale Sendingraad en die Christenraad daarmee dus wel bestaan het. ${ }^{24}$ )

So is die lidmaatskap van die enigste Afrikaanse kerk op die Christenraad offisieel beëindig. Na ds. Nicol se houding, soos hierbo weergegee, en moontlik die feit dat ds. Reyneke as sendingsekretaris bedank het om ' $n$ beroep na Pretoria aan te neem, was daar waarskynlik weinig belangstelling in voortgesette lidmaatskap van die Christenraad. Dit was egter wel 'n ongewone verloop van sake dat 'n Sinodale Kommissie eenvoudig ' $n$ vorige sinodebesluit, om wel by die Christenraad aan te sluit, sommerso negeer het.

Ter wille van ' $n$ juiste perspektief moet daar op 'n paar sake gelet word. Die Afrikaner-nasionalisme het in daardie jare hoog opgevlam. Ds. Nicol was 'n kwarteeu lank in Johannesburg predikant (1913-38) waar die stryd om die handhawing van Afrikaans baie fel was. Verder het die Ned. Geref. Kerke na jarelange worsteling, in 1935 'n eenvormige sendingbeleid geformuleer en daarna met meer selfvertroue na vore gekom en die regering met verskeie versoeke genader, bv. 'n verbod op gemengde huwelike, aparte woongebiede ens. Om in daardie tyd as minderheid saam op ' $n$ raad te gedien het met ander kerke wat ' $n$ ander rigting wou inslaan, was bepaald nie maklik nie. Die stigting van die Federale Sendingraad ${ }^{25}$ ) het sekerlik ook 'n baie groot rol gespeel. Dié raad het gevoel dat hulle tog met die Christenraad sou kon beraadslaag indien nodig maar aan die ander kant voort kon gaan binne 'n groep wat dieselfde siening oor rasse-aangeleenthede gehuldig het.

In dié verband het iemand die interessante vraag gevra, of dit toevallig was dat samewerking geblom het in 1936 (twee jaar na die samesmelting in die politiek wat die Verenigde Party tot stand gebring het) en onmoontlik geword het in 1939 na die 'onvergeetlike Eeufeesjaar' soos dit genoem is en met die konsolidasie van die eng nasionale elemente na 
die uitbreek van die oorlog en die besluit van die parlement om saam met die geallieerde magte te veg? ${ }^{26)}$

Alles in ag genome, is dit nogtans baie jammer dat, soos ds. Nicol dit self gestel het, ter wille van die getuienis van die kerk in Suid-Afrika, die Ned. Geref. Kerke nie met die ander kerke kon saamgaan nie. 'n Geleentheid om mekaar eerstehands te hoor en saam te soek na die waarheid, is daardeur deur die vingers laat glip.

\section{Verdere kontak}

Tydens die volgende jare was daar geen kontak met die Christenraad nie. Op die sinode van die Transvaalse kerk is die saak van aansluiting by die Christenraad weer te berde gebring en na die Raad van Kerke en die Federale Sendingraad verwys en aan die Sinodale Kommissie was volmag verleen om, indien die ander gefedereerde moeder- en sendingkerke sou aansluit, dit ook te doen. Op voorstel van dr. B J Marais en ds. $J$ Reyneke is ' $n$ spesiale kommissie aangestel om samesprekings te hou met verteenwoordigers van die ander Protestantse kerke in Suid-Afrika met die oog op 'n "uiterste poging tot nouer samewerking" op sendinggebied, desnoods deur uitbouing van die bestaande Christenraad of deur die daarstelling van ' $n$ nuwe breë skakelliggaam. ${ }^{27)}$ Transvaal het dus weer eens kans gesien om met die Christenraad saam te werk.

Hierdie kommissie het aan die sinode van 1954 gerapporteer dat twee van hulle lede ' $n$ vergadering van die Christenraad in 1952 in Kaapstad bygewoon het en verskeie samesprekings met verteenwoordigers van ander kerke gehou het. Die hele doel van die instelling van hulle kommissie was egter verwesenlik in en oorgeneem deur die Federale Sendingraad se pogings wat uitgeloop het op 'n groot konferensie met al die kerkleiers van erkende kerke en sendinggenootskappe in November 1953. Verdere optrede deur die spesiale kommissie sou slegs tot onnodige versplintering van kragte lei. ${ }^{28)}$ Vanaf 1953 het die Ned. Geref. Kerk inderdaad die leiding geneem om konferensies vir Afrikaans- en Engelstalige kerke te reël en later ook interkerklike veelrassige konferensies. ${ }^{29)}$

In 1954 het ds. J Reyneke die Transvaalse kerk op die vergadering van die Christenraad verteenwoordig. Dit was skynbaar die laaste amptelike kontak tussen die Christenraad en die Ned. Geref. Kerk. ${ }^{30)}$ Die Christenraad het op 31 Maart 1953 'n brief aan die Raad van Kerke gerig om gemeenskaplike optrede te vra na aanleiding van die toestande waaronder groot getalle mense van alle rasse in die stede lewe. Die Raad van Kerke het die Christenraad om ' $n$ memorandum oor die beoogde optrede gevra en 'n kommissie aangewys om na bevind van sake op te 
tree. ${ }^{311}$

Op die Cottesloe-beraad in Desember 1960 het die deelnemers van die agt ledekerke van die Wêreldraad van Kerke besluit om by hul kerke aan te beveel dat ' $n$ Suid-Afrikaanse konferensie van lede van die Wêreldraad van Kerke gestig word. ${ }^{32}$ ) Nadat die besluite van die Cottesloe-beraad deur die onderskeie sinodes van die Afrikaanse kerke veroordeel was en die Ned. Geref. Kerke in die Kaap en Transvaal uit die Wêreldraad van Kerke uitgetree het, het daar helaas niks van dié voorstel tereggekom nie.

\section{Die Christenraad word Suid-Afrikaanse Raad van Kerke (SARK)}

Die Christenraad het in 1958 besluit om die beperking op die bespreking van sake van geloof en orde op te hef en verskillende studies kon toe onderneem word. In 1962 is die hoofkantoor na Kaapstad verskuif en is besluit om by die Wêreldraad van Kerke te affilieer. Dit het tot ' $n$ groter verwydering tussen die Christenraad en die Afrikaanssprekende kerke in Suid-Afrika gelei. ${ }^{33)}$ In 1967 is biskop Bill Burnett as sekretaris van die Christenraad aangestel en die hoofkantoor na Johannesburg teruggeskuif. In 1968 is 'n nuwe grondwet aanvaar en die naam verander na Suid-Afrikaanse Raad van Kerke. Die sendingfase was verby en voortaan was daar 'n groter betrokkenheid by maatskaplike, ekonomiese en politieke vraagstukke in Suid-Afrika. Dit het spanning tussen sommige kerke veroorsaak en die Church of the Nazarene, die Baptiste Kerk en die Heilsleër het uit die SARK bedank.

Tot diep in die sestigerjare was die SARK redelik onbekend. lemand het baie skerp oor die Raad geoordeel: "It was not taken too seriously by its member churches or those in authority. It was virtually unknown to the public. In short, it was ill-suited and ill-equipped to serve the churches in a time of crisis." 34 ) In 1968 het die "Boodskap aan die volk van Suid-Afrika" deur die teologiese kommissie van die SARK verskyn. Die kern van die boodskap was om aan te toon dat apartheid en afsonderlike ontwikkeling strydig met die evangelie van Jesus Christus is. Die boodskap is aan al die predikante in Suid-Afrika gestuur en 600 het dit onderteken. Met die uitsondering van 'n paar lidkerke, o.a. die Baptiste, het die ander die boodskap onderskryf.

Die gevolge was verreikend. Die kloof tussen die SARK en die Afrikaanse kerke het wyer geword. Die dialoog tussen die groepe is bemoeilik want dit het diegene wat afsonderlike ontwikkeling teologies regverdig het, veroordeel. Die verhouding tussen die staat en die kerke wat aan die SARK behoort het, was gespanne. Dit het die SARK 'n 
status gegee wat hy vroeër nie gehad het nie. Dit het baie leraars en lidmate van alle kerke opnuut laat besin oor hul taak en roeping as Christene in hierdie land. Baie van die wat apartheid veroordeel het se eie lewe was ' $n$ ontkenning van hul belydenis. ${ }^{35 \text { ) }}$

\section{Die Algemene Sinode en die SARK}

Na die eenwording van die Ned. Geref. Kerke in een sinode in 1962 was die Breë Moderatuur (BM) verantwoordelik vir ekumeniese skakeling met ander kerke. Die Christenraad (later die SARK) het oor 'n hele verskeidenheid sake met die Breë Moderatuur in verbinding getree. Trouens, die sekretaris. Basil Brown, het die beleid gevolg om alle belangrike sake van die Raad na die Ned. Geref. Kerk te verwys om hulle medewerking te verkry of hulle te versoek om onafhanklik op te tree oor die betrokke saak. Hy het gemeen dat welwillendheid daardeur opgebou is, al was daar meningsverskil oor die sake. So is daar gesamentlik opgetree oor die afkondiging van huweliksgebooie. ${ }^{36}$ )

Op 11 Julie 1963 het Brown aan die Breë Moderatuur geskrywe en die Raad se besorgdheid uitgespreek oor die tragiese verdeeldheid van die kerke en die geringe skakeling met die Afrikaanse kerke. Ten spyte van diepgewortelde historiese redes vir die geskeidenheid, het hy daarop gewys dat die Here gelowiges roep om gemeenskaplike broederskap te erken. Die Christenraad het voorgestel dat daar vertroulike samesprekings tussen die kerke gehou word (maar nie 'n tweede Cottesloe wat hul bevindings aan die pers vrystel nie) om te soek na nuwe weë om saam te werk. Hulle het gedink aan 60 persone (30 van die Afrikaanse kerke en 30 van die Christenraad) wat vir 4 of 5 dae byeen sou kom. Op 26 November 1963 het ds. Burger namens die BM geantwoord dat hulle nie oor kontensieuse sake soos rasseverhoudinge wou konfereer nie maar wel oor sake in verband met die kerklike lewe en leer. Op 28 Februarie 1964 het Brown voorgestel dat die Ned. Geref. Kerk 3 of 5 persone benoem om 'n gelyke getal van die Christenraad te ontmoet. Op 21 Mei 1964 het die BM laat weet dat hulle nie ongeneë is om verteenwoordigers te benoem nie, maar hulle het gevoel dat die huidige tydstip nie die gewenste oomblik was nie. ${ }^{37)}$

Die Algemene Sinodale Sendingkommissie het op versoek van die Breë Moderatuur by twee geleenthede verteenwoordigers gestuur na konferensies oor sendingaangeleenthede wat deur die Christenraad gereël is. ${ }^{38 \text { ) }}$

'n Kontensieuse saak was die versoek van die Christenraad op 12 Desember 1963 aan die moderator van die Algemene Sinode (dr. A J van der Merwel om 'n verklaring te onderteken waarin geprotesteer word 
teen die sg. 90 dae aanhoudingsklousule. Die Breë Moderatuur het die Christenraad geantwoord dat die Raad nog nooit teen die gevare en bedreiginge en liggame wat ons staat en volksbestaan bedreig, gewaarsku of opgetree het nie. In die oorlogsjare het die kerke nie geprotesteer toe mense sonder aanklag of verhoor opgesluit was nie. Die kerk het dit betreur dat so 'n wet noodsaaklik geword het maar hulle kon hulle nie laat gebruik tot 'n protesaksie waaraan o.a. Jode en Mohammedane aan 'n godsdienstige samekoms sou deelneem en selfs uit die Koran gelees sou word nie. ${ }^{39 \text { ! }}$

Op 17 Augustus 1964 het die Christenraad die Ned. Geref. Kerk se siening gevra oor mense wat gewetensbesware teen militêre diens gehad het. Op 21 April 1965 het die BM geantwoord dat die Ned. Geref. Kerk nooit pasifisme as Skriftuurlik aanvaar het nie. ${ }^{401}$

'n Saak wat die Christenraad ook omgekrap het, was die reaksie op hulle versoek aan die Ned. Geref. Kerk om saam met hulle beswaar aan te teken oor die weiering van die regering om sekere godsdienstige werkers in Suid-Afrika toe te laat. Die BM het geantwoord dat hulle reeds met die regering geskakel het in dié verband en tevrede was met die minister se verduideliking. Indien die Christenraad verdere inligting verlang het, moes hulle met dr. J D Vorster skakel. Dit het hulle gedoen, waarop Vorster laat weet het dat hy persoonlik met die betrokke departement onderhandel het en nadat hulle al die feite aan hom verstrek het, het hy hulle optrede verstaan. Daarop het die sekretaris, Bill Burnett aan die BM geskrywe dat die Christenraad ongelukkig was oor die feit dat 'n leraar van 'n ander kerk mag weet waarom sekere mense nie permitte kon kry nie, terwyl die kerke wat daarom aansoek gedoen het, nie die inligting kon kry nie. ${ }^{41}$ Geen wonder dat die Ned. Geref. Kerk daarvan beskuldig was dat hy ' $n$ noue verbintenis met die regering gehad het nie.

Die Breë Moderatuur wou ook nie meedoen aan die SARK se poging om 'n ekumeniese navorsingseenheid daar te stel nie "omdat ons kerk sy eie ekumeniese verbintenisse het". Die BM het ook laat weet dat hulle nie wou meedoen aan 'n gesamentlike studiegroep om bepaalde sake, soos die besluite van die Gereformeerde Ekumeniese Sinode te Lunteren oor rasseaangeleenthede, te bespreek nie. Ten opsigte van die "Boodskap aan die volk van Suid-Afrika" het die BM die SARK laat weet dat die Engelse vertaling van die besluite van die jongste vergadering van die Algemene Sinode insake rasseverhoudinge, genoegsame antwoord op die stukke van die SARK was. ${ }^{42}$

Daar was ook verdere briefwisseling tussen drs. J D Vorster en J S Gericke en die SARK waarin lg. versoek het dat die gesprek voortgesit moes word. Die BM het egter van hulle verwag om sekere gewraakte woorde in die "Boodskap aan die volk" amptelik en in die openbaar terug 
te trek. ${ }^{43}$ )

By die Nasionale Konferensie van die SARK te Hammanskraal op 23 Julie 1975 is besluit om weer 'n uitnodiging aan die Ned. Geref. Kerk te rig "to consider with great urgency entry or re-entry into the fellowship of the Churches and Christians represented in the SACC 1) in view of the fact that Christian witness in South Africa will be incomplete without their contribution; 2 ) in view of the fact that a) in spite of differences in Church structure, Church doctrine, differences in political opinion and social standing; $b$ ) in spite of historical reasons which may in the past have led to the N.G. Kerk relinquishing its membership with the SACC, it is vital for a full spectrum of Christian opinion in South Africa to have a common platform for the discussion of issues affecting the teaching, preaching and practice of the Christian faith in the context of the South African situation. It is the express desire of the Executive Committee of the South African Council of Churches to make this a reality."

Die BM het op 19 Augustus 1975 aan John Rees laat weet dat, kragtens Kerkorde Art. 70.4 (wat lui dat oor ekumeniese betrekkinge met 'n twee-derde meerderheid van die sinode beslis moet word) dit nie binne die $B M$ se bevoegdheid lê om aan die uitnodiging uitvoering te gee nie. Die sinode het die optrede van die BM goedgekeur. ${ }^{44)}$ Formeel gesproke het die BM volkome gelyk met sy optrede gehad, maar uit die sinode se handelinge lyk dit asof die sinode ook nie verder op die versoek van die SARK ingegaan het nie.

Op 26 Oktober 1976 het die sekretaris van die SARK, John Rees, 'n brief aan die moderator, ds. D P M Beukes, geskrywe en gepleit vir die herstel van gemeenskap. Hy het gevra wat dan verkeerd is met die SARK. Beukes het geantwoord dat hulle, (die N.G.K.) in verslae en agendas byna uitsluitlik, volgens persberigte, politieke en nie-kerklike sake gevind het. ${ }^{45)}$ Dit is natuurlik onbillik om 'n ander kerk op grond van persberigte te beoordeel want die pers is baie selektief en soek nuuswaardige berigte.

Die SARK was nie klaar met die Ned. Geref. Kerk nie. Die Uitvoerende Komitee het op sy vergadering van 29 tot 30 September 1977 besluit om die hoogste voorkeur te verleen aan pogings om dialoog met die N.G. Kerk te voer. Daarom is besluit dat dit 'n staande punt op die agenda van elke vergadering sou wees. ${ }^{46)}$ Dr. F E O'B Geldenhuys, wat sedert 1975 die direkteur van ekumeniese sake van die N.G. Kerk was, het op versoek die jaarvergadering van die SARK in 1976 toegespreek oor die onderwerp "The Church's role in liberation". Die Uitvoerende Komitee van die SARK het op hul vergadering op 30 Nov. tot 1 Des. 1977 besluit om 'n staande uitnodiging aan dr. Geldenhuys te rig om as 
waarnemer alle vergaderings van die Uitvoerende Komitee by te woon. Die BM het daarop besluit om op grond van fundamentele verskille tussen die N.G. Kerk en die SARK nie die uitnodiging te aanvaar om 'n waarnemer te benoem nie maar dat kontak deur middel van korrespondensie gehou mag word. In die notule van die Algemene Sinode staan daar dat van die hele punt kennis geneem is. ${ }^{471}$

Die SARK het in die sewentigerjare verander van ' $n$ instelling wat deur blankes oorheers is na een wat meer verteenwoordigend van die swart Christengemeenskap geword het en dit het gekulmineer in die verkiesing van biskop D Tutu in Maart 1978 as algemene sekretaris. Die beleid en programme het al meer die swart Christelike mening weerspieël waardeur die SARK onder groter verdenking by die regering gekom het en verder verwyder van die blanke mening, selfs binne die lidkerke, geraak het. ${ }^{48 \prime}$

Op 4 Julie 1980 het prof. J A Heyns en dr. P Rossouw 'n afvaardiging van die SARK in Johannesburg ontmoet ${ }^{49}$ ) maar detail daaroor is nie bekend nie. Die BM het in 1982 by die Sinode aanbeveel dat, ten opsigte van die SARK, volstaan word met die besluit van 1978 dat die Ned. Geref. Kerk deur middel van korrespondensie met die SARK kontak hou. Die aanbeveling is egter deur die Sinode verwerp en die saak is na die Tydelike Kommissie vir Ekumeniese sake verwys wat op hulle beurt die aanbeveling van die BM ondersteun het. Die Sinode het dit andermaal verwerp en 'n amendement aanvaar "dat die sinode volstaan met die besluit van 1978 naamlik dat slegs kennis geneem word van wat die BM gedoen het. Daar bestaan dus geen bande tussen die N.G. Kerk en die SARK nie." 50 ' Van die BM se aanbeveling in 1978 is, soos ons aangedui het, net kennis geneem. Terwyl die BM in die reses geoordeel het dat hulle met korrespondensie kon voortgaan, het die sinode beklemtoon dat daar net kennis van geneem is en dus geen bande met die SARK bestaan het nie.

Op die Nasionale Konferensie van die SARK op 26 Junie 1986 is besluit om alle kerke in Suid-Afrika, maar in die besonder die Ned. Geref. Kerk, uit te nooi om by hulle aan te sluit. Lede van die Uitvoerende Komitee van die SARK het die dagbestuur van die BM op 2 Oktober 1986 ontmoet. Die sinode het hul aanbeveling aanvaar naamlik dat dit aan die BM opgedra word om na bevind van sake en/of wanneer daartoe versoek, informele samesprekinge met die SARK te voer ten einde 'n korrekte beeld van mekaar te bekom. ${ }^{511}$ Dit is ' $n$ baie welkome klimaatsverandering in vergelyking met die sinodebesluit van 1982. Twee Christenliggame kon ten minste nou weer met mekaar praat! 


\section{Slot}

Dr. Nicol het baie sterk argumente aangevoer vir deelneming aan die Christenraad, met veral die klem op samewerking, naamlik dat die eenheid van kerke daarmee sigbaar getoon word en boweal omdat ons dieselfde lewe in Jesus Christus deel. Hy het tereg aangetoon dat dit die enigste kerklike liggaam in Suid-Afrika was wat die geleentheid gebied het vir gesamentlike optrede deur die meeste Protestantse kerke.

Soos elders in ekumeniese gesprekke in die wêreld, het ook hier in Suid-Afrika geblyk dat, oor die algemeen, die Engelse kerke se kerkopvatting neig na 'n beklemtoning van die horisontale vlak van menseverhoudinge. In teenstelling daarmee, is byvoorbeeld die antwoord van die Breë Moderatuur in 1963 oor die algemeen ook tipies dat hulle nie oor rasseverhoudinge wou praat nie, maar oor kerklike lewe en leer. Hierdie twee beklemtonings moet mekaar egter aanvul want die waarheid bevat beide.

Die opkomende gety van Afrikaner-nasionalisme in die dertiger-en veertigerjare het ' $n$ groot rol gespeel. Die handhawing van Afrikaans en 'n ander siening as die Engelse kerke ten opsigte van die rassekwessie het tot botsings gelei. Binne die Ned. Geref. Kerk was vanaf die veertiger-tot sestigerjare 'n hewige debat gevoer oor die Skriftuurlike regverdiging van sy rassebeleid. Dit sou 'n geweldige sterk visie oor kerkeenheid verg om, ten spyte van al hierdie belemmerende faktore, aan 'n liggaam te behoort waarin in vele opsigte ' $n$ ander koers ingeslaan is. Maar sou die toetsing van die eie opvatting nie geweldig gebaat het indien daar ' $n$ voortdurende saamsoek met mense van ' $n$ ander standpunt was nie? Daar was diegene binne die Ned. Geref. Kerk wat steeds krities was oor die amptelike standpunt en per slot van rekening het die kerk algaande bewus geword van probleme met sy formulering en het op die laaste sinode verklaar "dat gedwonge afsonderlikheid en skeiding van volke nie as ' $n$ voorskrif uit die Bybel afgelees kan word nie. Die poging om so 'n voorskrif uit die Bybel te regverdig, moet as fout erken en afgewys word." ${ }^{52)}$ In die "Boodskap aan die volk van Suid-Afrika" is dit al in 1968 gesê.

In die sestigerjare het die Christenraad en SARK al meer standpunt ingeneem teenoor die regering se verskerpte maatreëls van beheer oor die swart volke. Die Ned. Geref. Kerk was soms ook ongelukkig oor sommige van die wette maar het altyd volgehou dat hulle stilweg die regering ontmoet om hul besware te lug en boweal dat hulle nie aan openbare protesaksies wou deelneem nie. Baie van die aksies van die SARK het 'n politieke kleur gehad maar die Ned. Geref. Kerk se versoeke in die veertigerjare om 'n verbod op gemengde huwelike en aparte woon- 
gebiede, het ook maar ' $n$ politieke kleur gehad.

Daar was wel ' $n$ besorgdheid by die Christenraad en later die SARK oor die verskeurdheid tussen die kerke en die gebrek aan skakeling. Hulle het in 1963, 1975 en 1986 die Ned. Geref. Kerk versoek om by hulle aan te sluit. Dit lyk my dat daar nie genoeg erns gemaak is met hierdie versoeke nie, veral nie met die byna hartstogtelike pleidooi van 1975 nie.

Daar moet egter ook realisties na die saak gekyk word. Die agendas van die SARK het miskien ander beklemtonings as die agendas van die Ned. Geref. Kerk. Dit is waarskynlik te wyte aan die feit dat die Ned. Geref. Kerk 'n blanke kerk is en sy behoeftes in sommige opsigte anders is as die van swart mense. Maar is hy nie daardeur armer en is sy visie op die Kerk van Christus nie meer beperk omdat hy net op homself (die blanke) toegespits is nie? Baie van die dinge wat die kerke uitmekaar hou, het nie te maak met die evangelie nie.

Die veranderende klimaat op politieke gebied het waarskynlik die veranderde houding in die Ned. Geref. Kerk vergemaklik. Die Afrikaner is deur sy storm en drang periode van die veertigs maar moet nou nuwe uitdagings die hoof bied. Die kerk in Suid-Afrika sal baie genade moet ontvang om as kerk, nou sy profetiese en priesterlike taak getrou uit te voer.

Alles in ag genome, is dit ' $n$ feit dat die SARK die grootste verteenwoordiger van die Kerk van Christus in Suid-Afrika is. Kan ons, die N.G. Kerk, ten spyte van al die hindernisse (en daar is baie want daar is ook baie onvolkomenhede in die SARK), bekostig om nie met die SARK te praat nie? Watter getuienis sal 'n groot sterk liggaam van kerke in SuidAfrika kan lewer teenoor die wêreld? Ek sluit af met die woorde van dr. Nicol tydens sy presidentsrede by die stigting van die Christenraad in 1936: "Isolation is death." 53 )

\section{NOTAS}

1. G B A Gerdener, Recent developments in the South African mission field. Kaapstad 1958, 168.

2. E Strassberger, Ecumenism in South Africa 1936-1960 with special reference to the mission of the church, Johannesburg 1974, 134-5, 157.

3. S.A. Outlook, 1 Aug 1929, 156-7; 2 Jan 1930, 1; 1 Apr 1931, 77; 1 Sept 1931, 177.

4. S.A. Outlook, 15 June 1934, 153-4.

5. S.A. Outlook, 1 Aug 1936, 174-5.

6. A C Viljoen, "Die ekumeniese polarisering van Afrikaanse en Engelse kerke van Suid-Afrika in fokus: die begin" New faces of Africa (Essays in honour of Ben (Barend Jacobus) Marais, edited by J W Hofmeyr and W S Vorster), Pretoria 1984, 194.

7. S.A. Outlook, 1 Sept. 1936, 203-208.

8. S.A. Outlook, 1 Oct. 1936, 231.

9. S.A. Outlook, 1 March 1937, 54-5. 
10. S.A. Outlook, 1 March 1937, 56-62.

11. Handelinge Raad van Kerke, 1935, 25, 94, 99-106.

12. Handelinge N.G. Kerk SA (Kaap), 1936, 73, 189, 227.

13. Handelinge Raad van Kerke, 1937, 16-19, 69-70, 72-76.

14. Handelinge N.H. of G. Kerk, 1937, 47, 79, 179, 269, 455.

15. Handelinge N.G. Kerk O.V.S., 1937, 25-6, 147.

16. Strassberger, a.w., 157-9.

17. Handelinge Raad van Kerke, 1939, 17, 67.

18. Handelinge Raad van Kerke, 1939, 17-18, 23-24.

19. S.A. Outlook, 1 May 1939, 109-111.

20. Handelinge N.H. of G. Kerk, 1940, 96, 402-404.

21. S.A. Out/ook, 1 Aug 1940, 150-151.

22. Handelinge N.G. Kerk S.A. (Kaap), 1940, 24, 202, 256. S A Outlook, 2 Dec 1940, $230-231$.

23. Strassberger, a.w., 163-164.

24. Handelinge N.H. of G. Kerk, 1944, 35 (no. 205), 52, 281, 361.

25. Viljoen noem dit die sleutel tot die verstaan van die frontverandering by die Ned. Geref. Kerk, a.w., 197.

26. Viljoen, a.w., 202.

27. Handelinge N.H. of G. Kerk, 1951, 439, 470.

28. Handelinge N.H. of G. Kerk, 1954, 263, 465.

29. W J van der Merwe, "Ekumeniese sendingaksie in Nederduitse Gereformeerde kring", Ned. Geref. Teologiese Tydskrif Vol. 16 (1, 1975); 95.

30. Strassberger, a.w., 167.

31. Handelinge Raad van Kerke, 1953, 64.

32. Cottes/oe consultation, Johannesburg 1961, 84

33. E P J Kleynhans, Gereformeerde Kerkreg, Deel 3, Pretoria 1985, 134.

34. J W de Gruchy. The Church struggle in South Africa, Cape Town 1979, 115.

35. A H Lückhoff, "Die Suid-Afrikaanse Raad van Kerke", Studia Historiae ECclesiasticae, Vol. 7 (1981), 107-109. De Gruchy, a.w. 122-123.

36. Secretary's Report, 5 May 1964, 2-3. (AC 623/4 Archives of Witwatersrand University).

37. Kaapse Kerkargief. AS 3/6: briefwisseling.

38. Handelinge Algemene Sinode, 1966, 187-188, 211, 521.

39. Handelinge Avgemene Sinode, 1966, 36-37, 505.

40. Kaapse Kerkargief, AS 3/6.

41. Kaapse Kerkargief, AS 3/6: briefwisseling 5/1/68, 1/11/68, 2/12/68, 14/4/69.

42. Kaapse Kerkargief, AS 3/6: briefwisseling 4/6/68, 1/11/68, 8/11/68, 29/5/69; Handelinge Alg. Sin., 1970, 35-36, 771.

43. Minutes Executive Meeting, 14-15 June 1972, 1; Handelinge Algemene Sinode, 1974, $29,564$.

44. Kaapse Kerkargief, AS 3/8; Handelinge Algemene Sinode, 1978, 63, 814.

45. Minutes Executive Committee, 7-8 Dec. 1976, 4 (SACC AC 623/17: 1-2 Arch. Wits. Univ.) Vgl. ook die verslag van die $A d$ hoc-kommissie oor die verhouding N.G.K. en SARK, 30 Nov-1 Des 1977.

46. Minutes Executive Committee, 29-30/9/77 2.

47. Minutes Executive Committee, 14-15/3/78, 6; 30/11-1/12/78, 5; 5-6/12/78, 8 . Handelinge Algemene Sinode 1978, 44, 800.

48. De Gruchy, a.w., 126.

49. Minutes $4 / 7 / 80$.

50. Handelinge Algemene Sinode, 1982, 99, 1188, 1065-66, 1329. 
51. Beeld, 27/6/86, 4; Handelinge Algemene Sinode, 1986. Sien tweede verslag van die Skriba en handelinge middagsitting $16 / 10 / 86$ punt 9.6 .5 (die gedrukte Handelinge is nog nie beskikbaar nie).

52. Kerk en samelewing, Bloemfontein 1986, 52 (par. 305).

53. Kyk noot 7 hierbo. 